Printed in Great Britain

\title{
NEMATODES PARASITIC ON SEA WEEDS OF THE GENERA ASCOPHYLLUM AND FUCUS
}

\author{
By JOHN W. Coles \\ Department of Zoology, British Museum (Natural History)
}

(Text-figs. I-3)

In I892 Barton described galls found on the sea weed Ascophyllum nodosum from the Isle of Cumbrae, west coast of Scotland, and from Stonehaven, east coast of Scotland. The affected areas on the thallus of the plant appeared as swellings covered with small rounded nodules, and were almost invariably confined to the parts of the thallus just above or below the air vesicles. A transverse section through the swellings showed each nodule as a more or less hollow space containing numerous nematodes, specimens of which were sent to J. G. de Man, who (1892) described the worm as a new species, Tylenchus fucicola, the first-known marine tylenchid.

On the basis of de Man's description Cobb (N. A. Cobb in M. V. Cobb, I933) erected the genus Halenchus for this species. Since then, other species of Halenchus have been described, but only as free-living forms.

From time to time galls on other sea weeds have been reported, but attributed to other animal agents, bacteria and fungi.

During visits by the author to the Laboratory of the Marine Biological Association at various times during $1955-57$ galls were found very commonly on Ascophyllum nodosum in the Plymouth area (Wembury Bay). They agree well with Barton's description and contain numerous specimens of a nematode, which appears to be identical with de Man's form. Similar galls were also found at Croyde Bay on the north Devon coast in August 1955 (Fig. I A).

Galls were also found on the sea weed Fucus vesiculosus (Fig. IB) from Wembury Bay, Devon, and at Hannafore, Looe, Cornwall. They were found only on the older growths of the plant and occurred mainly on the stipes, and less frequently on the base of the fronds. The galls are quite noticeable and are usually a little lighter in colour than the rest of the stipes, but are not so large as some of those seen on Ascophyllum. The surface of the swellings is rugose and not so papillate as the galls on the other plant. When the galls were opened nematodes were found, but there were only a few in each in contrast with the galls on Ascophyllum which contain large numbers. At first the worms were thought to be identical with Halenchus fucicola, except that the anterior end appeared rather larger. On closer examination, however, 
several small differences have been noted and are considered to be of sufficient significance to warrant the recognition of a distinct species.

Frequently non-tylenchid nematodes are found in the galls as well as the marine mite Rhombognathus (Rhombognathopsis) seahami (Hodge), kindly identified by Dr G. O. Evans. The nematodes appear to represent a variety of species no one of which appears to be consistently present; thus leading one to conclude that they are not the causal agents.

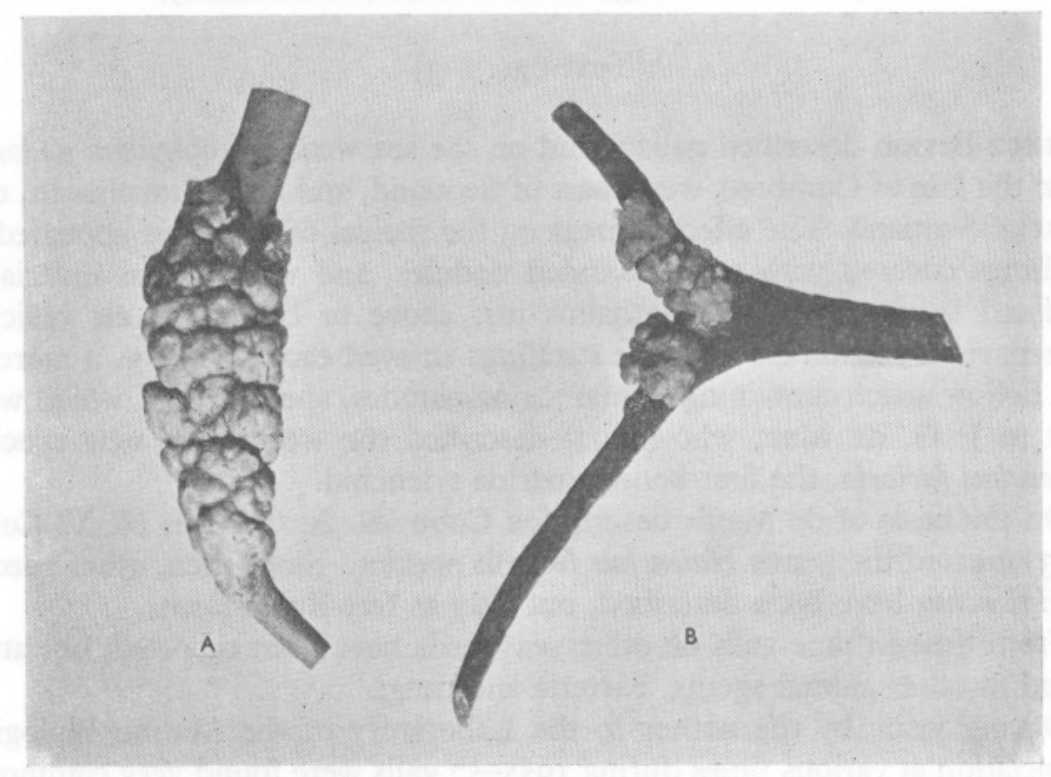

Fig. I. Galls on (A) Ascophyllum nodosum, and (B) Fucus vesiculosus.

(Approx. natural size.)

During a one-day visit to Lyme Regis, Dorset, in July I957, galls were seen on the stipes of Fucus vesiculosus, and in some plants there were also galls on the fronds. In this locality galls were also seen on the stipes of $F$. serratus. On examination, these were found to be very similar to those on $F$. vesiculosus, and contained the same species of nematode.

The examination of the nematodes in the above material has been based on living specimens, as well as on others killed by heat, fixed in formalin and subsequently cleared in lactophenol and glycerine.

A redescription is given below of Halenchus fucicola, together with a description of the new species, $H$. dumnonicus. ${ }^{1}$

1 From the Dumnonii, the British tribe that inhabited the south-west. 
Halenchus fucicola (de Man, I892) Cobb, 1933

Tylenchusfucicola de Man, I892. Festschr. zum Siebenzigsten Geburtstag Rudolf Leuckart, pp. I2I-5.

Anguillulina fucicola, Goodey, 1932. F. Helminth. Vol. ro, p. 27.

Halenchus fucicola, Cobb, 1933. F. Parasit. Vol. 20, p. 94.

Type host. In galls on the sea weed Ascophyllum nodosum Le Jol.

Material studied. From galls on A. nodosum, Wembury Bay, Devon, August 1955, June 1956, and May 1957.

Dimensions. Given in Table I.

Long slender worms, gradually tapering at the extremities, with a characteristic hook-like tail, bent ventrally in both sexes. The cuticle is faintly transversely striated. The striations, which appear to be absent on the headregion, being about $\mathrm{I} \mu$ apart. Lateral fields are present, which are about oneeighth of the body thickness; they appear to start at about half-way between the anterior end of the body and the excretory pore and can be traced to the tail region.

The head is marked off by a slight constriction, this latter being about $6 \mu$ in diameter. There appear to be no distinct lips, the head-framework being divided into six sectors defined by faint ridges. Papillae are present on the two subdorsal and two subventral sectors, and the openings of the amphids are on the lateral ones. The amphidial pouches are situated laterally on either side of the stylet (Fig. 2C). The stylet is fairly well developed (I5-I6 $\mu$ long in the males and $15-18 \mu$ long in the females) and is divided into two portions, a cylindrical posterior portion, with three well-pronounced basal knobs, and a conical anterior portion (Fig. 2C, D).

The excretory pore and its duct are well defined and characteristic, being heavily cuticularized. The pore is situated ventrally about one-eighth of the body length from the anterior end and the duct runs spirally in a posterior direction. The oesophagus is poorly developed. About mid-way along its length there is a slight swelling of the oesophageal wall associated with which is a somewhat ellipsoid widening of the lumen, probably representing a middle bulb. The lumen of the oesophagus can be seen in living specimens to have a wavy outline. The junction of the oesophagus and intestine is not clear, and was only seen in living specimens, where it occurred at about $20-25 \mu$ anterior to the excretory pore. The granulated material of the intestine was seen to commence at this region and sometimes could be seen to run anteriorly into the oesophagus. Close behind the nerve ring, which is situated at the posterior end of the oesophagus, a dorsal oesophageal gland emerges from the wall of the oesophagus as a glandular diverticulum running alongside the intestine. This gland has a fairly well-defined nucleus and opens into the lumen of the oesophagus about $2-3 \mu$ behind the base of the stylet. The distance of the extremity of the gland from the anterior 
TABLE 1. DIMENSIONS OF HALENCHUS FUCICOLA (DE MAN, 1892) FROM WEMBURY BAY

\begin{tabular}{|c|c|c|c|c|c|c|c|c|}
\hline Sample & & $\underset{\substack{\text { Body } \\
\text { length }}}{(\mu)}$ & $\frac{\text { Body length }}{\text { Body thickness }}$ & $\frac{\text { Body length }}{\text { Excretory pore }}$ & 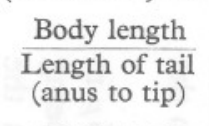 & $\frac{\text { Body length }}{\text { Length of stylet }}$ & $\frac{\text { Body length }}{\text { Length of spicules }}$ & $V(\%)$ \\
\hline August I955, ठิ & $\begin{array}{l}\text { Range } \\
\text { Mean } \\
\text { Standard deviation } \\
\text { No. of specimens }\end{array}$ & $\begin{aligned} & 800-970 \\
& 891 \\
& \pm 55 \cdot 26 \\
& 10\end{aligned}$ & $\begin{array}{l}34 \cdot 58-48 \cdot 50 \\
38 \cdot 10 \\
\pm 7 \cdot 08 \\
\text { 10 }\end{array}$ & $\begin{array}{l}7 \cdot 17-8 \cdot 18 \\
7 \cdot 78 \\
\pm 0 \cdot 28 \\
\text { I0 }\end{array}$ & $\begin{aligned} & 10.90-12.93 \\
& 11 \cdot 73 \\
& \pm 0.63 \\
& 10\end{aligned}$ & $\begin{aligned} & 51 \cdot 90-64 \cdot 67 \\
& 58 \cdot 67 \\
& \pm \\
&+1.16 \\
& \text { I0 }\end{aligned}$ & $\begin{aligned} & 36 \cdot 36-43 \cdot 00 \\
40 \cdot 70 & \\
\pm & 2 \cdot 18 \\
& 10\end{aligned}$ & z \\
\hline August 1955, 우 & $\begin{array}{l}\text { Range } \\
\text { Mean } \\
\text { Standard deviation } \\
\text { No. of specimens }\end{array}$ & $\begin{array}{l}970-1120 \\
1052 \cdot 70 \\
\pm \\
\pm 4.50 \\
\text { II }\end{array}$ & $\begin{array}{l}32 \cdot 50-46 \cdot 67 \\
40 \cdot 52 \\
\pm 5 \cdot 45 \\
\text { II }\end{array}$ & $\begin{aligned} & 7 \cdot 30-9.55 \\
& 8.51 \\
& \pm 0.56 \\
& \text { II }\end{aligned}$ & $\begin{aligned} & 10 \cdot 18-13 \cdot 75 \\
& 12 \cdot 95 \\
\pm & 1 \cdot 49 \\
8 & \end{aligned}$ & $\begin{aligned} & 60 \cdot 62-70 \cdot 00 \\
& 65 \cdot 45 \\
\pm & 3 \cdot 31 \\
& \text { II }\end{aligned}$ & $\begin{array}{l}\text { Z } \\
\text { - }\end{array}$ & $\begin{aligned} & 60 \cdot 00-68 \cdot 0 \\
& 62 \cdot 17 \\
\pm & 2 \cdot 44 \\
9 & \end{aligned}$ \\
\hline June $1956,0 \widehat{0}$ & $\begin{array}{l}\text { Range } \\
\text { Mean } \\
\text { Standard deviation } \\
\text { No. of specimens }\end{array}$ & $\begin{aligned} & 820-970 \\
& 883 \\
& \pm 48 \cdot 31 \\
& \text { I0 }\end{aligned}$ & $\begin{aligned} & 35 \cdot 38-5 I \cdot I I \\
& 42 \cdot 06 \\
\pm & 4 \cdot 69 \\
& 10\end{aligned}$ & $\begin{array}{l}7 \cdot 39-8 \cdot 94 \\
8 \cdot 11 \\
\pm 0 \cdot 44 \\
\text { I0 }\end{array}$ & $\begin{array}{l}10.90-13.14 \\
11.63 \\
\pm 0.75 \\
9\end{array}$ & $\begin{aligned} & 45 \cdot 55-64 \cdot 67 \\
& 56 \cdot 50 \\
& \pm 5 \cdot 45 \\
& 10\end{aligned}$ & $\begin{aligned} & 37 \cdot 27-45 \cdot 00 \\
& 41 \cdot 68 \\
\pm & 2 \cdot 12 \\
& 10\end{aligned}$ & $\begin{array}{l}\bar{z} \\
-\end{array}$ \\
\hline June 1956 , 와 & $\begin{array}{l}\text { Range } \\
\text { Mean } \\
\text { Standard deviation } \\
\text { No. of specimens }\end{array}$ & $\begin{array}{l}980-1100 \\
\text { I056 } \\
\pm 41 \cdot 35 \\
\text { I0 }\end{array}$ & $\begin{aligned} & 33 \cdot 44-49 \cdot 52 \\
& 41 \cdot 69 \\
\pm & 4 \cdot 96 \\
& \text { I0 }\end{aligned}$ & $\begin{array}{l}8.00-9.48 \\
8.85 \\
\pm 0.48 \\
\\
\text { I0 }\end{array}$ & $\begin{aligned} & 12 \cdot 22-\mathrm{I} 5 \cdot 00 \\
& \mathrm{I} 3 \cdot 48 \\
& \pm \mathrm{I} \cdot 06 \\
& 6\end{aligned}$ & $\begin{aligned} & 61 \cdot 25-73 \cdot 33 \\
& 66 \cdot 46 \\
\pm & 3 \cdot 55 \\
& 10\end{aligned}$ & $\begin{array}{l}- \\
-\end{array}$ & $\begin{aligned} & 59 \cdot 09-64 \cdot 00 \\
& 61 \cdot 37 \\
\pm & 1 \cdot 55 \\
& 10\end{aligned}$ \\
\hline May I957, ठోరి & $\begin{array}{l}\text { Range } \\
\text { Mean } \\
\text { Standard deviation } \\
\text { No. of specimens }\end{array}$ & $\begin{aligned} & 920-1060 \\
& 963 \\
\pm & 43 \cdot 72 \\
10 & \end{aligned}$ & $\begin{aligned} & 35 \cdot 92-45 \cdot 91 \\
& 42 \cdot 20 \\
& \pm 3 \cdot 57 \\
& 10\end{aligned}$ & $\begin{array}{l}7 \cdot 36-7 \cdot 92 \\
7 \cdot 67 \\
\pm 0.17 \\
9\end{array}$ & $\begin{aligned} & 11 \cdot 05-12 \cdot 80 \\
& 11 \cdot 87 \\
\pm & 0.57 \\
& 8\end{aligned}$ & $\begin{aligned} & 57 \cdot 50-67 \cdot 33 \\
& 62 \cdot 18 \\
\pm & 3 \cdot 19 \\
& 10\end{aligned}$ & $\begin{aligned} & 40 \cdot 00-55 \cdot 71 \\
& 44 \cdot 08 \\
\pm & 5 \cdot 07 \\
& 9\end{aligned}$ & $\begin{array}{l}- \\
-\end{array}$ \\
\hline May 1957, & $\begin{array}{l}\text { Range } \\
\text { Mean } \\
\text { Standard deviation } \\
\text { No. of specimens }\end{array}$ & $\begin{array}{l}\text { I0 } 40-1430 \\
\text { II } 59 \\
\pm 46 \cdot 80 \\
\text { I0 }\end{array}$ & $\begin{array}{rl} & 33 \cdot 94-49 \cdot 26 \\
& 42 \cdot 51 \\
\pm & 4 \cdot 98 \\
9 & 9\end{array}$ & $\begin{array}{l}7 \cdot 47^{-8 \cdot 22} \\
7 \cdot 84 \\
\pm 0 \cdot 28 \\
8\end{array}$ & $\begin{aligned} & 12 \cdot 18-14.05 \\
& 12 \cdot 99 \\
\pm & 0 \cdot 71 \\
& 8\end{aligned}$ & $\begin{aligned} & 61 \cdot 17-79 \cdot 44 \\
& 68 \cdot 43 \\
\pm & 6 \cdot 17 \\
& \text { I0 }\end{aligned}$ & z & $\begin{aligned} & 59 \cdot 6 \mathrm{I}-65 \cdot 76 \\
& 63 \cdot 76 \\
\pm & \mathrm{I} \cdot 99 \\
8 & \end{aligned}$ \\
\hline
\end{tabular}

The ratio body length/excretory pore has been used instead of the usual ' $b$ ' (body length/oesophagus) because of the difficulty of determining the posterior limit of the oesophagus. $V$ is the distance of the vulva from the anterior end of the body expressed as a percentage of the body length.

TABLE 2. DIMENSIONS OF HALENCHUS DUMNONICUS SP.NOV. FROM WEMBURY BAY, 1955, 1956, 1957, AND HANNAFORE, LOOE, 1956

\begin{tabular}{|c|c|c|c|c|c|c|c|c|}
\hline Sample & & $\begin{array}{c}\text { Body } \\
\text { length } \\
(\mu)\end{array}$ & $\frac{\text { Body length }}{\text { Body thickness }}$ & $\frac{\text { Body length }}{\text { Excretory pore }}$ & 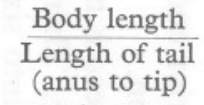 & $\frac{\text { Body length }}{\text { Length of stylet }}$ & $\frac{\text { Body length }}{\text { Length of spicules }}$ & $V(\%)$ \\
\hline$\widehat{o} \widehat{0}$ & $\begin{array}{l}\text { Range } \\
\text { Mean } \\
\text { Standard deviation } \\
\text { No. of specimens }\end{array}$ & $\begin{aligned} & 850-1200 \\
& 989 \cdot 10 \\
\pm & 38 \cdot 15 \\
& \text { II }\end{aligned}$ & $\begin{aligned} & 33 \cdot 85-46 \cdot 15 \\
& 40 \cdot 09 \\
\pm & 3 \cdot 27 \\
& \text { II }\end{aligned}$ & $\begin{array}{l}6 \cdot 44-7 \cdot 84 \\
7 \cdot 20 \\
\pm 0.52 \\
10\end{array}$ & $\begin{array}{l}9 \cdot 56-13.33 \\
11 \cdot 12 \\
\pm 1 \cdot 23 \\
10\end{array}$ & $\begin{aligned} & 39 \cdot 54-57 \cdot 14 \\
& 47 \cdot 57 \\
\pm & 6 \cdot 12 \\
& \text { II }\end{aligned}$ & $\begin{aligned} & 35 \cdot 42-50 \cdot 00 \\
& 40 \cdot 45 \\
\pm & 4 \cdot 26 \\
& \text { II }\end{aligned}$ & - \\
\hline 우우 & $\begin{array}{l}\text { Range } \\
\text { Mean } \\
\text { Standard deviation } \\
\text { No. of specimens }\end{array}$ & $\begin{aligned} & 900-1480 \\
& 1091 \cdot 20 \\
\pm & 166 \cdot 55 \\
& 16\end{aligned}$ & $\begin{aligned} & 30 \cdot 86-47 \cdot 62 \\
& 39 \cdot 41 \\
+ & 4 \cdot 79 \\
& 16\end{aligned}$ & $\begin{array}{l}6.43-9.31 \\
7.52 \\
\pm 0.76 \\
\text { I2 }\end{array}$ & $\begin{aligned} & 9 \cdot 69-11 \cdot 95 \\
& 10.96 \\
& \pm 0.75 \\
& 10\end{aligned}$ & $\begin{aligned} & 42 \cdot 86-6 r \cdot 36 \\
& 50 \cdot 76 \\
\pm & 5 \cdot 08 \\
& 16\end{aligned}$ & $\begin{array}{l}- \\
-\end{array}$ & $\begin{array}{l}64 \cdot 76-88 \cdot 89 \\
69 \cdot 94 \\
\pm 6 \cdot 20 \\
\quad 12\end{array}$ \\
\hline
\end{tabular}


end of the body varies from I55 to $253 \mu$. The intestine terminates in a short rectum.

Deirids were not seen, while phasmids are present on the tail in the posterior region of the lateral caudal alae in the males, and occur in the region about half-way between the anus and the tip of the tail in the females.

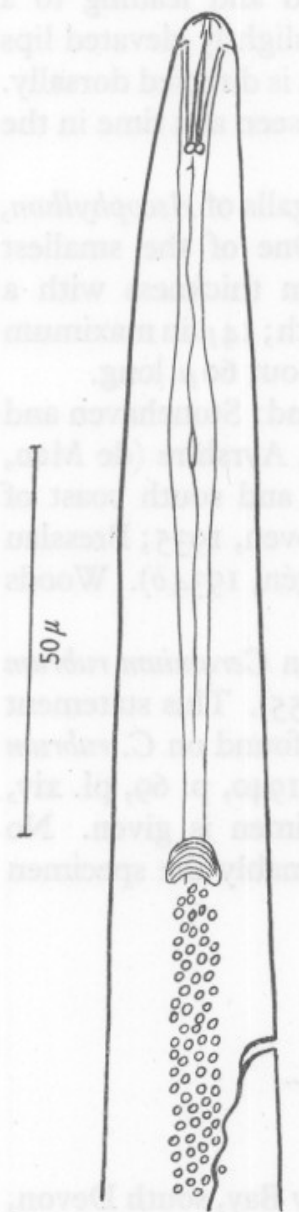

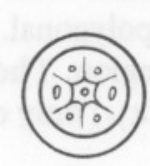

B

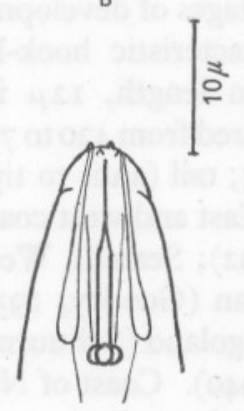

C

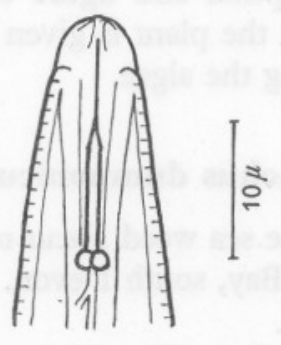

D

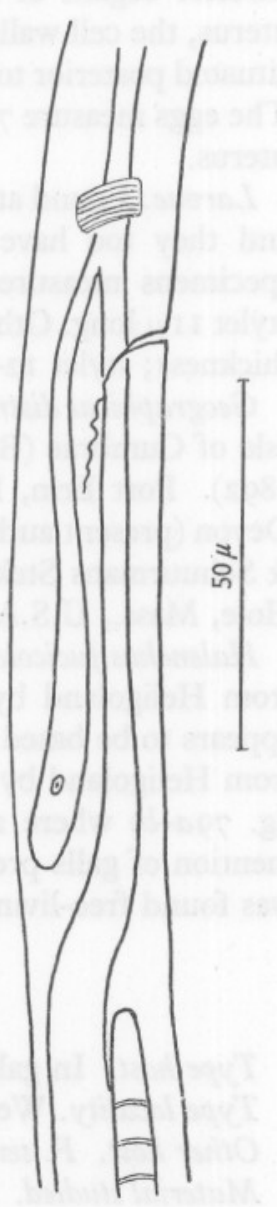

E

Fig. 2. A, Halenchus fucicola, anterior end; B, H. fucicola, head (en face); c, H. fucicola, head (ventral view showing papillae and amphids) (B and $\mathrm{C}$ to same scale); D, H. fucicola, head (lateral view); E, H. dumnonicus, posterior oesophageal region (lateral view).

Male. Testis single and straight, commencing at the anterior region of the intestine, opening without any apparent constriction into a vas deferens, which ends in a short ejaculatory duct. Spicules paired and equal, arched, 
with slight variations, $20-24 \mu$ in length (Fig. 3C, F and G). Gubernaculum trough-like, about $6-7 \mu$ in length in a lateral view. Lateral alae present, commencing just anterior to proximal end of spicules and extending to about mid-way between cloaca and tip of tail.

Female. Ovary single and straight, anterior to vulva, and commencing at anterior region of intestine. Oviduct well differentiated and leading to a uterus, the cell walls of which are polygonal. Vulva with slightly elevated lips situated posterior to middle body region. The short vagina is directed dorsally. The eggs measure $75-80 \mu$ by $23-24 \mu$; only one has been seen at a time in the uterus.

Larvae: Found at various stages of development in the galls of Ascophyllum, and they too have the characteristic hook-like tail. One of the smallest specimens measured $330 \mu$ in length, I2 $\mu$ in maximum thickness with a stylet II $\mu$ long. Others measured from 420 to $730 \mu$ in length; I $4 \mu$ in maximum thickness; stylet I2-I $3 \mu$ long; tail (anus to tip of tail) about $60 \mu$ long.

Geographical distribution. East and west coast of Scotland: Stonehaven and Isle of Cumbrae (Barton, I892); Seamill, West Kilbride, Ayrshire (de Man, I892). Port Erin, Isle of Man (Goodey, I932). North and south coast of Devon (present author). Heligoland (Schuurmans Stekhoven, I935; Bresslau \& Schuurmans Stekhoven, 1940). Coast of Norway (Allgén, 1934b). Woods Hole, Mass., U.S.A. (Chitwood, I95I).

Halenchus fucicola has also been reported as parasitic on Ceramium rubrum from Heligoland by Schuurmans Stekhoven (1935, p. I55). This statement appears to be based on the one immature male specimen found on C. rubrum from Heligoland by Bresslau \& Schuurmans Stekhoven (I940, p. 69, pl. xiv, fig. $79 a-b)$ where a description and figure of the specimen is given. No mention of galls present on the plant is given and presumably the specimen was found free-living among the algae.

\section{Halenchus dumnonicus sp.nov.}

Type host. In galls on the sea weed Fucus vesiculosus L.

Type locality. Wembury Bay, south Devon.

Other host. F. serratus L.

Material studied. From galls on F. vesiculosus, Wembury Bay, south Devon, August 1955, June 1956, May I957; and Looe, Cornwall, June 1956.

Holotype. oิ, B.M. No. I955, II.I.301. Allotype. †, B.M. No. I955, I I . I . 302. Paratypes: B.M. No. 1955, I I . I . 303-3I I (5 10 0ิ, 4 우); I957, 8. I . II2 (6 ํํ, 6 우). Host material registered under B.M. No. I955, I I. I.3I2325. I957, 8. I. I3-16.

Dimensions. Given in Table 2.

The shape of the body is very similar to that of Halenchus fucicola except that the anterior end is much more strongly developed in proportion to the 
total length of the worm, and the stylet, although of similar shape to the other form, is much longer $(20-22 \mu$ long in the males and $20-25 \mu$ long in the females). The tip of the tail is again hook-like, bent ventrally in both sexes.

The transverse striations of the cuticle, lateral fields, structure of the head and papillae are the same as in H. fucicola.

The excretory pore and its duct bear a considerable resemblance to those seen in $H$. fucicola, although the duct does not appear to be quite so heavily cuticularized and is situated ventrally about one-eighth of the body length from the anterior end. The structure of the oesophagus is also similar to that of the other species and the nerve ring is situated at the posterior end of it. The connexion of the oesophagus with the intestine is not clear in this species also and occurs just posterior to the nerve ring, about $20-25 \mu$ anterior to the excretory pore. The dorsal oesophageal gland usually appears more slender than it does in the previous species, but this structure is somewhat variable in size. In some of the preserved and cleared specimens the connexion of the gland and the wall of the oesophagus is more easily seen (Fig. 2E). The opening of the gland into the lumen of the oesophagus occurs at about $2-3 \mu$ from the base of the stylet. The distance of the extremity of the gland from the anterior end of the body is about $200 \mu$. The intestine is as in H. fucicola.

Deirids have not been seen. The phasmids have not been seen in this form.

Male. Testis and vas deferens as in H. fucicola. Spicules are longer, stouter and differ in shape from those in the other form (2I-27 $\mu$ in length). In lateral view a well-pronounced protuberance can be seen raised in the form of a hump on the ventral side in mid-region; towards the proximal end there is also a greater curvature (Fig. 3D, H). Gubernaculum is trough-like, about $7 \mu$ in length in a lateral view. Lateral alae are present as in $H$. fucicola.

Female. Ovary, oviduct and uterus similar to that in H. fucicola. Two specimens were found each bearing an egg; in one case the egg measured 66 by $22 \mu$ and in the other 108 by $27 \mu$. Vulva with slightly elevated lips, situated posterior to the middle body region. Seen in a lateral position the vagina appears to have a greater cuticular development than in $H$. fucicola (Fig. 3E). A short post-vulvar uterine sac is present.

Larvae. Not seen.

Geographical distribution. South Devon and south Cornwall; Lyme Regis, Dorset.

The new species is a slightly larger form and differs from $H$. fucicola principally in the greater development of the stylet and in the shape of the spicules. In $H$. fucicola the males average about $900 \mu$ in length and the females, including those bearing an egg, average just over 1000 $\mu$. Only one specimen was found as long as $1430 \mu$ and specimens over I I00 $\mu$ are not common. The maximum body thickness varies from I 8 to $28 \mu$ in the males and $20-33 \mu$ in the females. In $H$. dumnonicus the males average about $1000 \mu$ in length and the females about $\mathrm{I} 100 \mu$. Only two gravid specimens were 

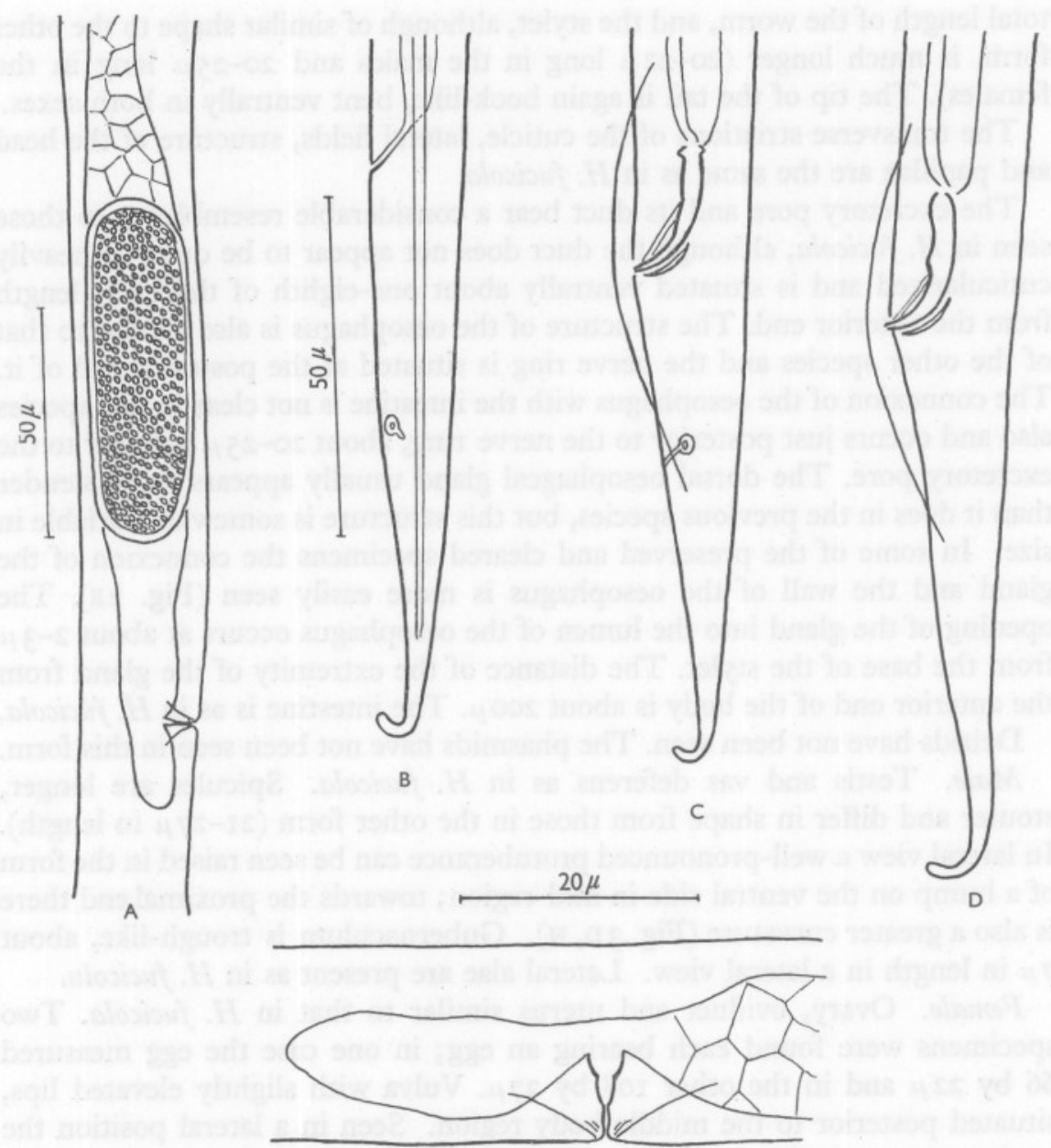

E
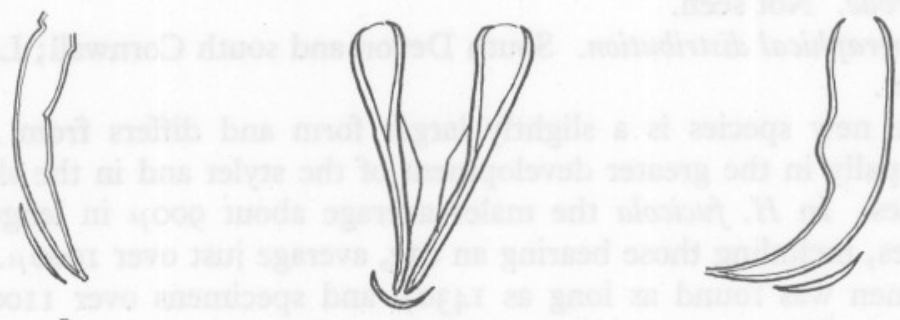

$F$

$10 \mu$

G

Fig. 3. A, Halenchus fucicola, posterior uterine region with egg; B, H. fucicola, female tail (showing lateral field and phasmid); C, H. fucicola, lateral view of male tail; D, Halenchus dumnonicus, lateral view of male tail (B, C and D to same scale); $\mathrm{E}, H$. dumnonicus, posterior uterine region; F, $H$. fucicola, lateral view of spicule and gubernaculum; $\mathrm{G}, H$. fucicola, ventral view of spicules and gubernaculum; $\mathrm{H}, \mathrm{H}$. dumnonicus, lateral view of spicule and gubernaculum ( $\mathrm{F}, \mathrm{G}$ and $\mathrm{H}$ to same scale). 
found, each bearing one egg and measuring 1240 and $1270 \mu$ in length respectively. The maximum body thickness varies from 20 to $31 \mu$ in the males and $2 \mathrm{I}-38 \mu$ in the females.

The samples considered here are not random because the intention during sampling was to get some idea of the full range of size, so that the number of large and small specimens measured is probably biased in favour of such individuals. As a result of this it is valueless to compare the means of the absolute measurements. The difficulty, however, can be overcome by comparing ratios: while appreciating that ratios may also vary due to differential growth. For example, in $H$. fucicola the ratio body length/stylet length is 30 at a larval body length of $330 \mu, 35$ at $420 \mu$ and 56 at $730 \mu$. In a sample of ten adults, mean body length $970 \mu$, the ratio is 59.60 ; and in another sample of Io adults, mean body length $I I 59 \mu$, it is $68 \cdot 43$. These values were obtained by dividing a sample of twenty individuals into two halves on the basis of body length. From these figures it can be seen that the body grows at a greater rate than the stylet.

Ratios have been calculated for body length/body thickness, body length/ distance of excretory pore from anterior end, body length/tail length, body length/stylet length, body length/length of spicules, and the distance of the vulva from the anterior end expressed as a percentage of the body length, i.e. vulva $\times$ IOo/body length. The mean body lengths, given in the tables, are in all cases not significantly different, so that the ratios calculated against them should be strictly comparable. The ratios were calculated for all specimens and means and standard deviations calculated for them. Of these only the ratios of body length/length of stylet are significantly different in the two forms.

Due to the low number of specimens, the measurements of $H$. dumnonicus have been lumped, and it is this total which has been compared to each sample of $H$. fucicola.

As mentioned earlier, the specimens in the galls of Fucus vesiculosus are much scarcer, and when living specimens are removed from the galls they are usually more active than those of Halenchus fucicola from Ascophyllum. Specimens are also scarce in the galls on Fucus serratus.

Of the remaining species of Halenchus, ${ }^{1} \mathrm{H}$. dumnonicus differs from $H$. mediterraneus (Micoletzky, 1922) in the length of the stylet, the position of the caudal alae, which do not extend so far posteriorly, and in the size and shape of the gubernaculum, which is smaller and has a wavy outline.

Finally, the new species differs from H. mexicanus Chitwood, I95I, in the shape of the tail, which is not hook-like.

1 Tylenchus (Chitinotylenchus) zostericola Allgén (1934a) found associated with Zostera in Holland was transferred to Halenchus by Chitwood (I95I), but is now considered to belong to the genus Radopholus (see Allen, I955). 
These tylenchid nematodes occur on the fucoid algae which predominate in the middle zone of the shore, and at Wembury Bay much time has been spent by the writer looking for galls on Fucus spiralis and F. serratus without success, although on a later visit to Lyme Regis galls were seen on the latter species.

Ascophyllum nodosum and Fucus vesiculosus occur at approximately the same height on the shore, and at Wembury Bay galls were sometimes seen on both plant species where they were growing near to each other. It would therefore seem possible for both species of nematodes to infest either plant, since at some stage in the life cycle some of the worms presumably emerge from the galls to infest new host plants. An obstacle to the elucidation of the life history of the worms by experimental means, however, arises from the difficulty of maintaining the large brown sea weeds under laboratory conditions.

Sometimes Halenchus fucicola and Halenchus sp. are quoted as parasites of red sea weeds, Furcellaria fastigiata, Chondrus crispus and Rhodymenia palmata. It appears, however, that these statements are based on the reports in two other papers by Barton (I89I, I90I). Barton's material of Furcellaria and Chondrus, which was found washed up at Lyme Regis in 1900, is in the algal collections of the British Museum (Natural History) and the writer has had the opportunity of examining it. Although the nematodes in the galls of these plants are in very poor condition they certainly do not appear to be tylenchids. According to Barton (I89I), the nematodes from Rhodymenia palmata were found in galls attributed to a copepod, and in a recent paper by Harding (1954), in which a description is given of the life history of the copepod from galls on Rhodymenia palmata, nematodes were again reported in some of the galls.

Thanks are due to Dr H. W. Parker who suggested this line of research, to $\mathrm{Mr}$ W. G. Inglis and Mr S. Prudhoe for much help and advice during the course of the work, and to the staff of the Laboratory at Plymouth, especially to Dr M. W. Parke.

\section{SUMMARY}

The nematode Halenchus fucicola (de Man), causing galls on the thallus of the sea weed Ascophyllum nodosum, has been found in the Plymouth area (Wembury Bay) and at Croyde Bay on the north Devon coast, and a redescription of the worm is given. A new species of Halenchus ( $H$. dumnonicus) causing similar growths on the sea weeds Fucus vesiculosus and F. serratus is described. This latter form is also found at Wembury Bay; at Looe, Cornwall, and at Lyme Regis, Dorset. 


\section{REFERENCES}

Allen, M. W., 1955. A review of the genus Tylenchorhynchus. Univ. Calif. Publ. Zool., Vol. 61, pp. 129-66.

ALLGÉN, C. A., 1934a. Freilebende marine Nematoden aus Hallands Väderö und der nahegelegenen Küste Schonens (Südschweden). Eine Beitrag zur Kenntnis der Nematoden fauna des südlichen Kattegatts. Folia zool. hydrobiol., Riga, Vol. 6, pp. 49-86.

— 1934b. Die marinen Tylenchen. Folia zool. hydrobiol., Riga, Vol. 6, pp. 86-7.

BARTON, E. S., I89I. On the occurrence of galls on Rhodymenia palmata Grev. 7. Bot., Lond., Vol. 29, pp. 65-8.

- I892. On malformations of Ascophyllum and Desmarestia. Phycol. Mem., Lond., Part I, pp. 2I-4.

- 1901. On certain galls in Furcellaria and Chondrus. F. Bot., Lond., Vol. 39, pp. 49-5I.

Bresslau, E. \& SchuUrmans Stekhoven, J. H., Jr., 1940. Marine Freilebende Nematoden aus der Nordsee, $74 \mathrm{pp}$. Bruxelles: Musée royal d'Histoire naturelle de Belgique.

ChItwood, B. G., 1951. North American marine nematodes. Texas f. Sci., Vol 3, pp. $617-72$.

Cовв, M. V., Ed., 1933. N. A. Cobb: New nemic genera and species, with taxonomic notes. F. Parasit., Vol. 20, pp. 81-94.

Goodey, T., I932. The genus Anguillulina Gerv. and v. Ben., I859, vel Tylenchus Bastian, 1865. F. Helminth., Vol. 10, pp. 75-180.

HARDING, J. P., I954. The copepod Thelastris rhodymeniae (Brady) and its nauplius, parasitic in the sea weed Rhodymenia palmata (L.) Grev. Proc. zool. Soc. Lond., Vol. I24, pp. 153-6r.

MAN, J. G. DE, I892. Über eine neue in Gallen einer Meeresalge lebende Art der Gattung Tylenchus Bast. Festschr. zum Siebenzigsten Geburtstag Rudolf Leuckart, pp. I2I-5. Leipzig: Wilhelm Engelmann.

Micoletzky, H., r922. Neue freilebende Nematoden aus Suez. S.B. Akad. Wiss. Wien, Math-Naturwiss. Kl., Abt. I, Bd. I31, pp. 77-103.

SchuUrmans Stekhoven, J. H., Jr., 1935. Nematoda errantia. Tierw. N.- u. Ostsee, Teil 5, b, I73 pp. (Lief. 28). 